\title{
Potency of secondary metabolites of Trichoderma asperellum and Pseudomonas fluorescens in the growth of cocoa plants affected by vascular streak dieback
}

\author{
MANIPPO SIMAMORA ${ }^{1}$, MOHAMMAD BASYUNI ${ }^{2}$, LISNAWITA ${ }^{1, \bullet}$ \\ ${ }^{1}$ Faculty of Agriculture, Universitas Sumatera Utara. Jl. Prof. A. Sofyan No. 3, Medan 20155, North Sumatra, Indonesia. Tel./fax.: +62-61-8213236, \\ vemail: lisnawita@usu.ac.id \\ ${ }^{2}$ Faculty of Forestry, Universitas Sumatera Utara. Jl. Tridharma Ujung No. 1, Medan 20155, North Sumatra, Indonesia
}

Manuscript received: 28 January 2021. Revision accepted: 13 April 2021.

\begin{abstract}
Simamora M, Basyuni M, Lisnawita. 2021. Potency of secondary metabolites of Trichoderma asperellum and Pseudomonas fluorescens in the growth of cocoa plants affected by vascular streak dieback. Biodiversitas 22: 2542-2547. Vascular streak dieback (VSD) is the main disease in cocoa caused by Oncobasidium theobromae. Using secondary metabolites of Trichoderma asperellum and Pseudomonas fluorescens is one of the methods to control disease in cocoa plants. The aim of this research is to evaluate the potency of secondary metabolites of T. asperellum and P. fluorescens to control VSD and study its effect on the growth of cocoa plants. The study used a non-factorial, completely randomized design (CRD) with eight treatments and four replications. The secondary metabolites were applied every week for ten times. The results showed that the secondary metabolites of T. asperellum and P. fluorescens were effective in controlling VSD. The combination of organic fertilizer and secondary metabolite of P. fluorescens and T. asperellum as found to be the best treatment to increase cocoa growth and the number of shoots increased by 43.58 shoots.
\end{abstract}

Keywords: Oncobasidium theobromae, Pseudomonas fluorescens, Trichoderma asperellum, vascular streak dieback

\section{INTRODUCTION}

Vascular streak dieback (VSD) is an important wood vessel disease on cocoa caused by Oncobasidium theobromae (Samuels et al. 2012). This fungus (Basidiomycetes) penetrates through the young leaves and then enters the network of wood vessels (xylem). Within 6 to 16 weeks (depending on the age and variety of the cocoa plant), symptoms appeared on the second and third leaves of the shoot (Harni et al. 2017). The most characteristic symptoms of the disease are green-spotted leaf chlorosis or necrotic blotches and blackening of infected xylem in the vascular traces at the leaf scars resulting in the abscission of infected leaves (Samuels et al. 2012).

The disease is invariably fatal if the infection occurs in the main stem of seedlings or clonal plants, but if the infection reaches the main stem of mature plants, the disease is usually fatal only in susceptible genotypes (Guest and Keane 2018). In susceptible cocoa, the fungus grows through the xylem down into the main stem and can kill a mature cocoa tree (Samuels et al. 2012). The disease can cause a decrease in the quality and quantity of cocoa production and attack all stages of the plant, from the seedling to the productive stage (Ekowati et al. 2009). According to Harni et al. (2019), the development of the disease is due to the interaction of several factors, such as planted clones, a wetter climate, improper plant cultivation systems (spacing, shade trees, terracing, and drainage), and minimal plant maintenance (crop pruning and shade, fertilization, garden sanitation, and pest and disease control).
Attempts have been made to control chemically, but maximum results have not been found, as VSD disease occurs in the bundle of wood vessels (xylem), making it difficult to access fungicides. Meanwhile, according to Syahnen (2011), systemic fungicides are usually transported through phloem, thus they cannot hit the fungus. Therefore, other alternatives are needed to control this disease. One of them is using secondary metabolites of biological control agents.

Secondary metabolites, secreted by entomopathogenic fungi, are a rich source of bioactive chemicals, including polyketides, non-ribosomal peptides, polyketide-peptide hybrid metabolites, and terpenes. Many of these secondary metabolites have been reported to have antifeedant and insecticidal properties (Elbanhawy et al. 2019; Subbanna et al. 2019). Keswani et al. (2019) stated that microbial pesticides are considered as imperative alternatives to chemical pesticides as they have high host specificity, biodegradability, and environmental safety.

Many studies have been conducted to explore the biocontrol capacity of biological agents to produce antibiotics that make them a target for the biological control of plant diseases, such as Trichoderma sp. and Pseudomonas fluorescens. According to Vinale et al. (2014), Trichoderma sp. produces hydrolytic enzymes such as $\beta-1,3$ glucanase, chitinase, and cellulase, which can dissolve pathogenic cell walls. Secondary metabolites of Trichoderma sp. can reduce the intensity of the disease by up to $62 \%$, caused by $O$. theobromae (Hutapea 2017). Furthermore, Soesanto et al. (2005) reported that $P$. fluorescens P19 and P. fluorescens P20 could suppress 
fusarium wilt disease in tomato plants by $23.42 \%$ and $28.20 \%$, respectively. Besides, Soesanto et al. (2010) stated that $P$. fluorescens P60 could be beneficial as it acted as plant-growth-promoting rhizobacteria and also has a tendency to increase plant height and root length. $P$. fluorescens P60 antagonist produces indole acetic acid which acts as growth support to increase the plant's dry weight. The objective of this study was to evaluate the effectiveness of secondary metabolites of T. asperellum and $P$. fluorescens for VSD and their effects on cocoa growth.

\section{MATERIALS AND METHODS}

\section{Study area}

The research was conducted in the cocoa plantation at Lau Mulgap Village, Selesai, Langkat District, North Sumatra, Indonesia, from July to September 2020. The plant samples were determined by random sampling of plants that showed symptoms of VSD attack, such as distinct leaf color toothless twigs, pimples, or rashes on twigs. Each sample plant was given a sign/label to facilitate observation.

\section{Experimental design}

This study used a non-factorial completely randomized design (CRD) with eight treatments and four replications. The treatments were as follows: P0 (control/without treatment), P1 (organic fertilizer), P2 (secondary metabolites of T. asperellum), P3 (secondary metabolites of $P$. fluorescens), P4 (organic fertilizers + secondary metabolites of $T$. asperellum), P5 (organic fertilizers + secondary metabolites of $P$. fluorescens), P6 (secondary metabolites of $T$. asperellum + secondary metabolites of $P$. fluorescens), and P7 (organic fertilizers + secondary metabolites of $T$. asperellum + secondary metabolites of $P$. fluorescens).

\section{Production of secondary metabolites}

Trichoderma asperellum and P. fluorescens isolates used in this study were identified and collected from the Field Laboratory of the Center for Seedlings and Plantation Protection, Medan. Preparation of secondary metabolites from T. asperellum and P. fluorescens was based on the method of Soesanto et al. (2005).

\section{Provision of organic fertilizer}

The organic fertilizer used in this research was flour organic fertilizer (Nitrogen $(0.69 \%), \mathrm{P}_{2} \mathrm{O}_{5}$ (3.18\%), Corganic $(17.02 \%), \mathrm{C} / \mathrm{N}(24.66 \%), \mathrm{pH}(8.72 \%)$, and water content (18.87\%). $5 \mathrm{~kg}$ per stem fertilizer was sprinkled on the stem area of the cocoa plant used as sample plants (based on dosage recommendations by the producer of Pamorganic Mas (CV. Utama Karya Tani).

\section{Treatment applications}

All cocoa plants were first treated with dolomite to improve soil $\mathrm{pH}$ so that plants could easily absorb nutrients from the soil. Moreover, maintenance pruning was also performed for all sample trees. $400 \mathrm{ml}$ secondary metabolites of each biological control agent were applied by root infusion technique at four points at 7 days of interval. A root infusion was carried out by inserting the roots of cocoa plant into a plastic bag containing a suspension of secondary metabolites of biological control agents (Figure 1.A). Furthermore, the plastic bag was covered with dry leaves (Figure 1.B).

\section{Phytochemical analysis}

A qualitative phytochemical analysis was performed to test the phenolic components such as saponin, tannin, and glycoside after the seventh week of application. Saponin analysis was carried out based on the modified method of Harbone (1984). Tannin analysis was carried out based on the modified method of Moelyono (1996). Glycoside analysis was performed based on the modified method of Kristianti (2008). The instrument used was the GCMSQP2010 Shimadzu. The column used was DB-5MS (nonpolar column). Its length was $30 \mathrm{~m}$, diameter $0.25 \mathrm{~mm}$, injector temperature $250{ }^{\circ} \mathrm{C}$, detector temperature $280{ }^{\circ} \mathrm{C}$, program temperature $40{ }^{\circ} \mathrm{C} / 2$ (increments of $10{ }^{\circ} \mathrm{C}$ per minute to $280{ }^{\circ} \mathrm{C} / 3$ ), pressure $68 \mathrm{Kpa}$, flow rate of 0.9 $\mathrm{mL} / \mathrm{min}$, and velocity $34.2 \mathrm{~L}$.

\section{Observation parameters}

The observation parameters included phytochemical analysis, level of efficacy, and increase in the number of shoots.

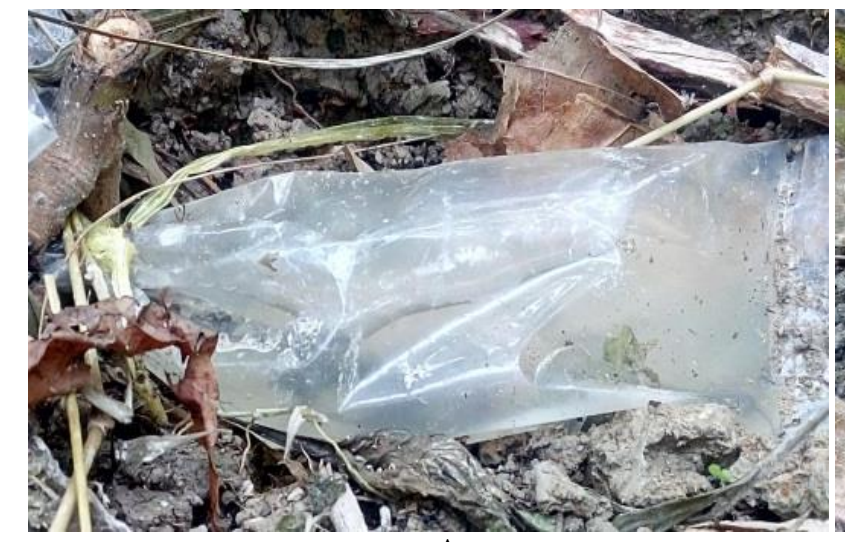

A

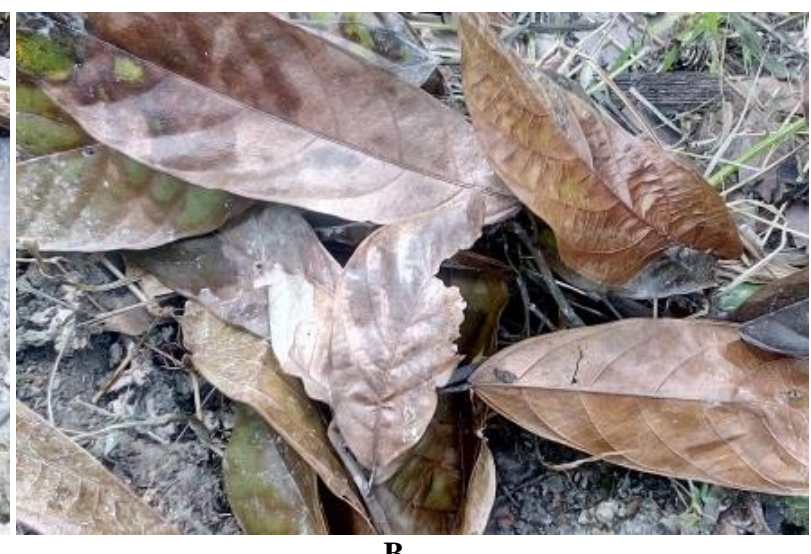

B

Figure 1. Application of secondary metabolites of biological control agents on cocoa roots. A. Root infusion using plastic bag containing secondary metabolites suspension, B. Covered with dry leaves 


\section{Data analysis}

The observational data were analysed with analysis of variance at an error level of 5\%. If there was a significant difference between treatments, then it is continued with the Tukey's test at the 5\% level (Sastrosupadi 2000).

\section{RESULTS AND DISCUSSIONS}

\section{Phytochemical analysis}

The results of the phytochemical analysis showed that all treatments contained phenolic compounds in the form of saponins, tannins, and glycosides. The content of saponins, tannins, and glycosides in the combined application treatment of T. asperellum and P. fluorescens secondary metabolites was higher than that in control (Table 1).

Phenolic compounds are found naturally in plants. Their function is to defend plants from pathogenic infections. Plant phenolics and their extracts can be excellent inhibitors of many foodborne pathogens (Gyawali and Ibrahim 2014; Zambrano et al. 2019). Inhibition of this signaling process can contribute to the biological control of pathogenic organisms and bacterial toxins causing food deterioration and/or poisoning (Nazzaro et al. 2013). Mandal et al. (2010) stated that phenolic compounds act as agents in plant defense. Phenolic will be synthesized by plants when plant receptors recognize the presence of potential pathogens (Newman et al. 2007) by conserved pathogen-associated molecular patterns (PAMPs), leading to PAMP-triggered immunity (Zipfel 2008). As a result, the progress of the infection is restricted long before the pathogen gains complete hold of the plant (Nicaise et al. 2009).

Plant-derived phenolics, such as phenolic acids, flavonoids, stilbenes, and tannins, can inhibit the growth and activity of many microorganisms, including foodrelated pathogens as well as clinically important bacteria, fungi, and protozoa (Daglia 2012; Schmidt et al. 2012; Li et al. 2014). Since the different molecules vary in their structure and chemical composition, they can display various antimicrobial effects, such as permeabilization and destabilization of the plasma membrane or inhibition of extracellular enzymes. Moreover, these mechanisms of action differ from traditional antibiotics, which could make plant phenolics effective against drug-resistant pathogens (Górniak et al. 2019).

In this study, saponins, tannins, and glycosides were high in the combined application treatment of $T$. asperellum and $P$. fluorescens. This is presumably because the secondary metabolites of $T$. asperellum and $P$. fluorescens in the tested cocoa plants were able to increase the saponins, tannins, and glycosides in the plants. This statement is in accordance with the results of research by Soesanto et al. (2013) that the application of antagonistic microbes can increase the content of phenolic compounds in plants.

The results showed that secondary metabolites of $T$. asperellum and $P$. fluorescens were quickly absorbed by cocoa plants as they were treated with the root infusion method. This condition increases the phenol content in plants. Agrios (2005) stated that the increase in phenols in the plants because the secondary metabolites of antagonistic fungi are absorbed by plants and translocated systemically to all parts of the plant, giving rise to substances that are responsible for affected resistance, including phenol compounds In addition to antagonistic fungi, Soesanto and Termoshuizen (2001), and Jankiewicz and Koltonowicz (2012) stated that P. fluorescens colonize roots to stimulate plants, increasing the production of secondary metabolite compounds so that they play a role in plant resistance. Hanada et al. (2010) reported that Trichoderma spp. is a plant growth promoter and biocontrol agent.

The combined treatment of $T$. asperellum and $P$. fluorescens secondary metabolites increases the amount of phenol in plants, proving that combination treatment can increase phenol compounds in tested cocoa plants, and also affects resistance to plant pathogens. The disease severity was found to be lower in the combined treatment of $T$. asperellum and $P$. fluorescens secondary metabolites compared to control (Figure 2). Soesanto et al. (2013) stated that phenol compounds are responsible for plant resistance to pathogen attack. Phenolic compounds have gained attention in food research as possible growth inhibitors of foodborne pathogens; many individual phenolics have promising anti-quorum sensing potential and can suppress biofilm formation and toxin production of food-related pathogens (Takó et al. 2020).

Table 1. Phenolic components in cocoa plants

\begin{tabular}{|c|c|c|c|}
\hline \multirow{2}{*}{ Treatments } & \multicolumn{3}{|c|}{ Phenolic compounds in cocoa plants } \\
\hline & Saponin & Tannin & Glycoside \\
\hline P0: Control (no treatment) & + & + & + \\
\hline P1: Organic fertilizer & + & + & + \\
\hline P2: Secondary metabolite of $T$. asperellum & ++ & ++ & ++ \\
\hline P3: Secondary metabolite of $P$. fluorescens & ++ & +++ & +++ \\
\hline P4: Organic fertilizer + secondary metabolite of $T$. asperellum & ++ & ++ & ++ \\
\hline P5: Organic fertilizer + secondary metabolite of $P$. fluorescens & ++ & +++ & +++ \\
\hline P6: Secondary metabolite of $T$. asperellum $+P$. fluorescens & +++ & +++ & +++ \\
\hline P7: Organic fertilizer + secondary metabolite of T. asperellum $+P$. fluorescens & +++ & +++ & +++ \\
\hline
\end{tabular}

Note: (+) sign indicated the intensity level of the colour. + : Low, ++ : Medium, +++ : High 


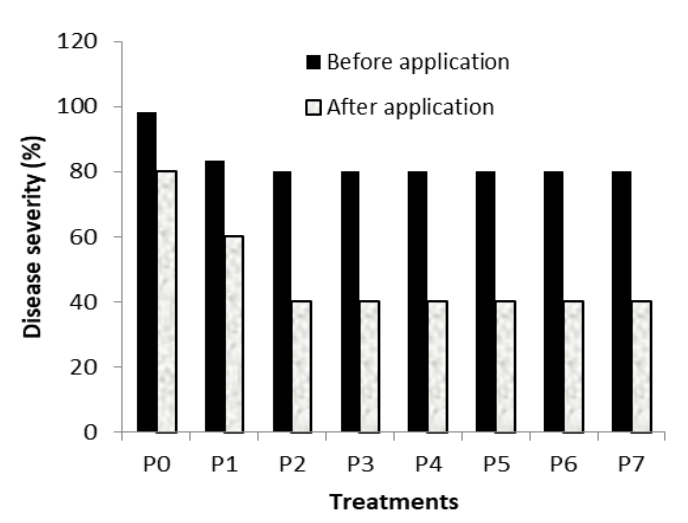

Figure 2. The effectiveness of secondary metabolites in reducing the disease severity of VSD in cocoa plants

Trichoderma sp. can stimulate plant-growth and biocontrol potential because disease severity was higher in control than other treatments that were directly proportional to the saponins, tannins, and glycosides in plants. This proves that the presence of phenolic compounds is very influential on plants attacked by pathogens. Lattanzio et al. (2006) reported that phenolic compounds in plants are secondary metabolites played a major role in the mechanism of plant resistance to fungal pathogens and insect herbivores attack.

\section{Level of efficacy}

The results of phytochemical analysis revealed that the treatment of secondary metabolites is quite effective in controlling VSD disease with an effective value of $40 \%$. The application of secondary metabolites of $T$. asperellum and $P$. fluorescens either alone or in combination gives the same effectiveness (P2, P3, P4, P5, P6, and P7; Figure 2). The effectiveness of secondary metabolites is good enough if the level of efficacy is greater than or equal to $30 \%$, provided that the level of damage in plants treated with secondary metabolites tested is lower than the level of damage in the control treatment (Aini 2014).

\section{Growth of shoot (The number of shoots)}

The growth parameters recorded in cocoa shoots were increase in number of shoots. It was measured by compare number of shoots before and after treatments. The results of the analysis of shoot growth variance are shown in Table 2.

Based on Table 2, the number of shoots that appeared between treatment P0 (control) and P1 (organic fertilizer) was significantly different; P1 treatment and secondary metabolites (P2, P3, P4, P5, P6, and P7) did not significantly different, and $\mathrm{P} 0$ treatment was significantly different with P1, P2, P3, P4, P5, P6, and P7.

Shoot growth (increase in number of shoots) after treatment between P2, P3, P4, and P6 was not significantly different but highly significantly different for P0 and P1. Treatments between P2, P3, P4, and P6 were not significantly different from treatment $\mathrm{P} 7$ but significantly different from P5.

The application of secondary metabolites can increase the number of shoots. The highest increase in number of shoots was recorded in treatment P5 (47.25 shoots) followed by treatment P7 (43.58 shoots), treatment P4 (38.58 shoots), treatment P3 (36.83 shoots), treatment P6 (36.25 shoots) and $\mathrm{P} 2$ treatment ( 34.75 shoots). While the lowest number of shoots i.e. (5.08 shoots) and (15.33 shoots) were recorded in P0 treatment and P1 treatment, respectively (Figure 3).

From Figure 3, it is evident that the number of shoots increased every week in all treatments. An increase in the number of shoots was not significant in the treatment without secondary metabolites (P0 and P1) but was found to be highly significant in the treatment with secondary metabolites (P2, P3, P4, P5, P6, and P7). The number of shoots did not increase in P0 treatment, as disease severity of VSD was very high, so the shoot growth could not achieve optimum results. As a result, leaf growth could not run properly, and if left unchecked, the plant would have died. According to Hutapea (2017), the attack of $O$. theobromae that causes chlorosis in leaves can interfere in the photosynthesis process, inhibiting growth. Furthermore, New lateral shoots will grow in the axillary of fallen leaves, but the lateral shoots will not grow normally and eventually dry out and die. Over time, the plant leaves will run out from the tip, giving the plant the appearance of a broom, and eventually leading to death. This is caused by an abnormal change in chloroplast function, which can inhibit the development of young tissue. The cause of chloroplast abnormalities is considered to be due to the presence of toxins released by pathogens.

Table 2. Effect of treatments on cocoa shoots growth

\begin{tabular}{lccc}
\hline Treatments & $\begin{array}{c}\text { The number of early } \\
\text { shoots } \\
\text { (before treatments) }\end{array}$ & $\begin{array}{c}\text { The number of } \\
\text { final shoots } \\
\text { (after treatments) }\end{array}$ & $\begin{array}{c}\text { Increase in } \\
\text { number of shoots }\end{array}$ \\
\hline P0: Control (no treatment) & $0.25 \mathrm{a}$ & $5.33 \mathrm{a}$ & $5.08 \mathrm{a}$ \\
P1: Organic fertilizer & $0.83 \mathrm{~b}$ & $16.17 \mathrm{~b}$ & $15.33 \mathrm{~b}$ \\
P2: Secondary metabolite T. asperellum & $1.17 \mathrm{bc}$ & $35.92 \mathrm{bc}$ & $34.75 \mathrm{bc}$ \\
P3: Secondary metabolite P. fluorescens & $1.17 \mathrm{bc}$ & $38.00 \mathrm{bc}$ & $36.83 \mathrm{bc}$ \\
P4: Organic fertilizer + secondary metabolite T. asperellum & $1.25 \mathrm{bc}$ & $39.83 \mathrm{bc}$ & $38.58 \mathrm{bc}$ \\
P5: Organic fertilizer + secondary metabolite P. fluorescens & $1.08 \mathrm{bc}$ & $48.33 \mathrm{~d}$ & $47.25 \mathrm{~d}$ \\
P6: Secondary metabolite T. asperellum + P. fluorescens & $1.58 \mathrm{~cd}$ & $37.83 \mathrm{bc}$ & $36.25 \mathrm{bc}$ \\
P7: Organic fertilizer + secondary metabolite T. asperellum + & $1.75 \mathrm{~d}$ & $45.33 \mathrm{~cd}$ & $43.58 \mathrm{~cd}$ \\
secondary metabolite P. fluorescens & & & \\
\hline
\end{tabular}

Note: Those numbers followed by the same letters indicated not significantly different by Tukey’s test at $\alpha=5 \%$ 


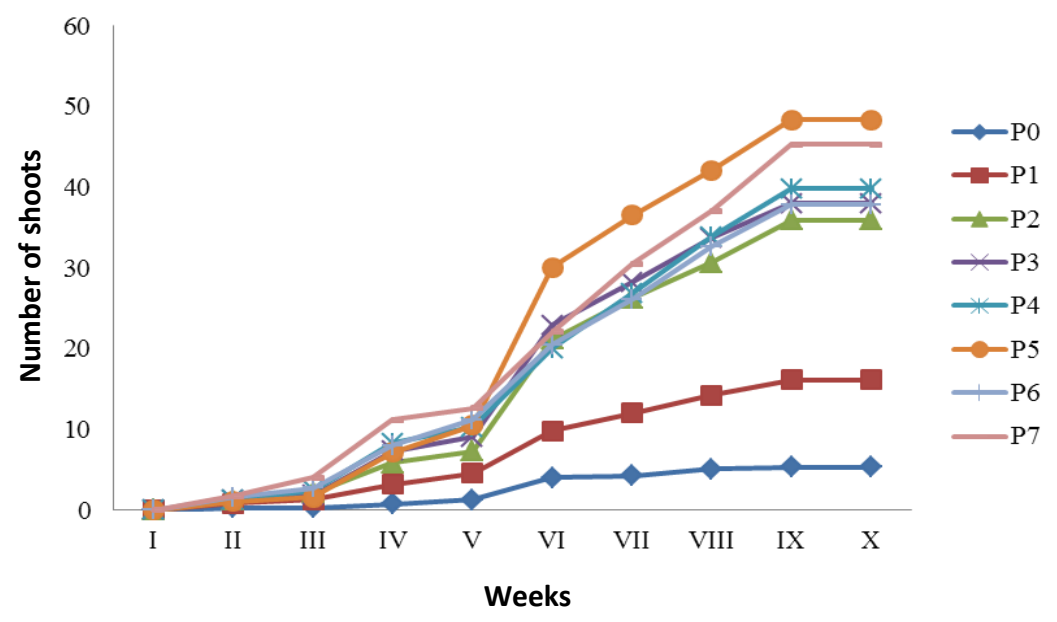

Figure 3. Increase in the number of shoots in each treatment

The increase in the number of shoots after treatment was due to the administration of secondary metabolites singly or to a combination of $T$. asperellum and $P$. fluorescens that could affect plant growth. This is in accordance with Soesanto et al. (2010), who reported that secondary metabolites of biological control agents play a dual role, both additively and synergistically, where these metabolites can not only overcome or control pests but are also able to trigger the growth and production of host plants. As per a previous study (Rosmana et al. 2019), the combination of $T$. asperellum and composted plant residues resulted in the highest decrease of VSD incidence that indicated a synergistic effect arising from a mixture of different mechanisms of the two treatments.

Trichoderma establishes symbiotic interactions with plants, and like other root-colonizing microorganisms such as rhizobia and mycorrhizae, these interactions can induce systemic resistance to plant diseases (Harman et al. 2008). According to Hyakumachi and Kubota (2003), the function of Trichoderma apart from being a biological control agent was also a plant growth-promoting fungus (PGPF). It has been reported that the mechanism of action of PGPF was known as a compound that functions as an antibiosis because it can produce antibiotics and growth hormones that can stimulate root extension so that plant growth can be better, increasing quality of yield, and improve plant health. Besides, Harni (2016) reported that as a biological agent, $P$. fluorescens is an endophytic bacterium that can increase plant growth because it produces growth hormones such as auxin and cytokinins. This indicates that the interaction between $T$. asperellum and P. fluorescens secondary metabolites affects the growth of cocoa plants.

It was observed that $\mathrm{P}$ fluorescence had a potential to suppress the development of VSD disease and to produce secondary metabolites as high growth regulators, which enhance the growth of cocoa plants. According to Nasrun and Nurmansyah (2016), the formula with the active ingredient of $P$. fluorescens Pf19 can induce the resistance of patchouli against Ralstonia Solanacearum which causes bacterial wilt disease, and increased patchouli plant growth. Hariprasad et al. (2013) showed that a tomato-rhizosphere- associated Pseudomonas sp. bacteria was able to produce the antimicrobial substance phenazine, which enhances intrinsic resistance in tomato root and attack of pathogens. It stimulated the intracellular accumulation of organic compounds (phenolics, lipoxygenase, and jasmonic acid) in the treated plant and provided protection against a wide range of pathogenic microbes (fungi, bacteria, and/or viruses).

In conclusion, secondary metabolites of $T$. asperellum and $P$. fluorescens were quite effective in controlling VSD and increasing cocoa growth as they reduced the severity of VSD by $40 \%$ and increased shoot growth by $43.58 \%$.

\section{REFERENCES}

Agrios GN. 2005. Plant Pathology. 5th ed. Academic Press, New York.

Aini FN. 2014. Control of vascular streak dieback disease of cocoa with Flutriafol fungicides. Pelita Perkebunan 30 (3): 229-239. DOI: 10.22302/iccri.jur.pelitaperkebunan.v30i3.43. [Indonesian]

Daglia M. 2012. Polyphenols as antimicrobial agents. Curr Opin Biotechnol 23:174-181. DOI: 10.1016/j.copbio.2011.08.007.

Ekowati N, Sucianto ET, Muljowati JS, Dewi R. 2009. Antibiotic activity test of several Gliocladium and Trichoderma isolates against pathogenic microbes with different initial $\mathrm{pH}$ of fermentation. Jurnal Inovasi 3 (2): 69-77. [Indonesian]

Elbanhawy AA, Elsherbiny EA, El-Mageed AEA, Abdel-Fattah GM. 2019. Potential of fungal metabolites as a biocontrol agent against cotton aphid. Aphis gossypii Glover and the possible mechanisms of action. Pestic Biochem Physiol 159: 34-40. DOI: 10.1016/j.pestbp.2019.05.013.

Górniak I, Bartoszewski R, Króliczewski J. 2019. Comprehensive review of antimicrobial activities of plant flavonoids. Phytochem Rev 18: 241-272. DOI: 10.1007/s11101-018-9591-z.

Guest DI, Keane PJ. 2018. Cacao disease: vascular-streak dieback. In: Umaharan P (eds) Achieving Sustainable Cultivation of Cocoa. Burleigh Dodds Science Publishing, Cambridge, UK. DOI: 10.19103/AS.2017.0021.18

Gyawali R, Ibrahim SA. 2014. Natural products as antimicrobial ag.ents. Food Control 46: 412-429. DOI: 10.1016/j.foodcont.2014.05.047

Hanada RE, Pomella AWV, Costa HS, Bezerra JL, Loguercio LL, Pereira JO. 2010. Endophytic fungal diversity in Theobroma cacao (cacao) and $T$. gradiflorum (cupuacu) trees and their potential for growth promotion and biocontrol of black-pod disease. Fungal Biol 114 (1112): 901-910. DOI: 10.1016/j.funbio.2010.08.006. 
Harbone JB. 1984. Phytochemical Methods. A Guide to Modern Techniques of Plant Analysis. 2nd ed. Chapman and Hall Publisher, New York.

Hariprasad P, Chandrashekar S, Brijesh Singh S, Niranjana SR. 2013. Mechanisms of plant growth promotion and disease suppression by Pseudomonas aeruginosa strain 2apa. J Basic Microbiol 54 (8): 1-10. DOI: 10.1002/jobm.201200491.

Harman GE, Bjorkman T, Ondik K, Shoresh M. 2008. Changing paradigms on the mode of action and uses of Trichoderma spp. for biocontrol. Outlooks Pest Manag 19 (1): 24-29. DOI 10.1564/19feb08.

Harni R, Amaria W, Syafaruddin, Mahsunah AH. 2017. Potential of Trichoderma spp. secondary metabolite in controlling vascular streak dieback (VSD) on cacao seedlings. Jurnal Tanaman Industri dan Penyegar 4 (2): 57-66. DOI: 10.21082/jtidp.v4n2.2017.p57-66. [Indonesian]

Harni R, Wahyudi D, Trisawa IM. 2019. Current research progress and strategy to control vascular streak dieback (VSD) disease of cacao. Perspektif 18 (2): 128-142. DOI: 10.21082/psp.v18n2.2019.120-134 [Indonesian]

Harni R. 2016. The prospect of developing endophytic bacteria as biological agents for controlling nematodes of plantation plant parasites. Perspektif 15 (12): 1412-8004. DOI: 10.21082/psp.v15n1.2016.31-49. [Indonesian]

Hutapea DS. 2017. Test of Secondary Metabolite Application of Two Isolates of Trichoderma harzianum and Pseudomonas fluorescens Against Cocoa Wood Vessel Disease. [Hon. Thesis]. Faculty of Agriculture. University of Soedirman, Purwokerto. [Indonesian]

Hyakumachi M, Kubota M. 2003. Fungi as plant growth promoter and disease suppressor. In: Arora DK (eds.). Fungal Biotechnology in Agricultural, Food and Environmental Application. Marcel Dekker, New York. DOI: 10.1201/9780203913369.ch9

Jankiewicz U, Kołtonowicz M. 2012. The involvement of Pseudomonas bacteria in induced systemic resistance in plants (review). Appl Biochem Microbiol 48 (3): 243-249. DOI 10.1134/S0003683812030052.

Keswani C, Singh HB, Hermosa R, García-Estrada C, Caradus J, He YW, Mezaache-Aichour S, Glare TR, Borriss R, Vinale F, Sansinenea E. 2019. Antimicrobial secondary metabolites from agriculturally important fungi as next biocontrol agents. Appl Microbiol Biotechnol 103 (23-24): 9287-9303. DOI: 10.1007/s00253-019-10209-2.

Kristianti A. 2008. Phytochemical Textbook. Department of Chemistry, FMIPA University of Surabaya, Surabaya. [Indonesian]

Lattanzio V, Lattanzio VMT, Cardinal A. 2006. Role of phenolics in the resistance mechanisms of plants against fungal pathogens and insects In: Imperato $\mathrm{F}$ (ed.). Phytochemistry: Advances in Research. Research Signpost, India

Li AN, Li S, Zhang YJ, Xu XR, Chen YM, Li HB. 2014. Resources and biological activities of natural polyphenols. Nutrients 6 (12): 6020 6047. DOI: 10.3390/nu6126020.

Mandal SM, Chakraborty D, Dey S. 2010. Phenolic acids act as signaling molecules in plant-microbe symbioses. Plant Signal Behav 5 (4): 359 368. DOI: $10.4161 /$ psb.5.4.10871.

Moelyono MW. 1996. Practicum Guide for Phytochemical Analysis. Pharmacology Laboratory. Department of Pharmacy. FMIPA University of Padjajaran, Bandung. [Indonesian]

Nasrun, Nurmansyah. 2016. Effectiveness of Pseudomonas fluorescens formulation to control bacterial wilt disease and to increase growth of patchouli plant. J Fitopatol Indonesia 12 (2): 46-52. DOI: 10.14692/jfi.12.2.46 [Indonesian]

Nazzaro F, Fratianni F, Coppola R. 2013. Quorum sensing and phytochemicals. Intl J Mol Sci 14 (6): 12607-12619. DOI: 10.3390/ijms140612607.

Newman MA, Dow JM, Molinaro A, Parrilli M. 2007. Priming, induction and modulation of plant defense responses by bacteria lipopolysaccharides. J Endotoxin Res 13 (2): 69-84. DOI: 10.1177/0968051907079399.

Nicaise V, Roux M, Zipfel C. 2009. Recent advances in PAMP triggered immunity against bacteria: pattern recognition receptors watch over and raise the alarm. Plant Physiol 150: 1638-1647. DOI: 10.1104/pp.109.139709.

Rosmana A, Taufik M, Asman A, Jayanti NJ, Hakkar AA. 2019. Dynamic of vascular streak dieback disease incidence on susceptible cacao treated with composted plant residues and Trichoderma asperellum in field. Agronomy 9 (10): 650. DOI: 10.3390/agronomy9100650.

Samuels GJ, Ismaiel A, Rosmana A, Junaid M, Guest D, Mcmahon P, Keane P, Purwantara A, Lambert S, Rodriguez-Carres M, Cubeta MA. 2012. Vascular streak dieback of cacao in Southeast Asia and Melanesia: in planta detection of the pathogen and a new taxonomy. Fungal Biol 116 (1): 11-23. DOI: 10.1016/j.funbio.2011.07.009.

Sastrosupadi A. 2000. Practical Experimental Design in Agriculture. Kanisius, Yogyakarta. [Indonesian]

Schmidt TJ, Khalid SA, Romanha AJ, Alves TMA, Biavatti MW, Brun R, Da Costa FB, De Castro SL, Ferreira VF, De Lacerda MVG. 2012. The potential of secondary metabolites from plants as drugs or leads against protozoan neglected diseases-part II. Curr Med Chem 19 (14): 2176-2228. DOI: 10.2174/092986712800229087.

Soesanto L, Mugiastuti E, Manan A, Wachjadi M. 2013. Ability test of several antagonists to control potato bacterial wilt in the field. Agrivita 35 (1): 30-35. DOI: 10.17503/Agrivita-2013-35-1-p030-035

Soesanto L, Mugiastuti E, Rahayuniati RF. 2010. Study of the mechanism of Pseudomonas fluorescens P60 antagonists against Fusarium oxysporum f.sp.lycopersici in tomato plants. Penyakit Tumbuhan Tropika 10 (2): $108-115$. DOI: $10.23960 /$ j.hptt.210108-115 [Indonesian]

Soesanto L, Soedharmono, Prihatiningsih N, Manan A, Iriani E, Pramono J. 2005. Potency of biological and vegetable agents in controlling ginger rhizome rot. J Hama Penyakit Tumbuhan Tropika 5 (1): 50-57. DOI: 10.23960/j.hptt.1550-1557. [Indonesian]

Soesanto L, Termoshuizen AJ. 2001. Potency of Pseudomonas fluorescens P60 as a biological control agent for soil-borne fungi. In: Phytopathology Role in Improving Agricultural Productivity and Product Quality in Sustainable Agribusiness Systems in XXI Century. Proceedings of the XVI National Congress and Scientific Seminar of Indonesian Phytopathological Society (PFI), Bogor, 22-24 August 2001. [Indonesian]

Subbanna ARNS, Stanley J, Rajasekhara H, Mishra KK, Pattanayak A, Bhowmick R. 2019. Perspectives of microbial metabolites as pesticides in agricultural pest management. In: Mérillon J-M, Ramawat KG (eds.). Co-Evolution of Secondary Metabolites. Springer Nature, Switzerland. DOI: 10.1007/978-3-319-96397-6_44

Syahnen. 2011. Recommendations for VSD Disease Control in Cocoa Plants in Pasaman District, West Sumatra, Andalas University, Padang. [Indonesian]

Takó M, Kerekes EB, Zambrano C, Kotogán A, Papp T, Krisch J, Vágvölgyi C. 2020. Plant phenolics and phenolic-enriched extracts as antimicrobial agents against food-contaminating microorganisms. Antioxidant 9 (2): 165. DOI: 10.3390/antiox9020165

Vinale F, Manganiello G, Nigro M, Mazzei P, Piccolo A, Pascale A, Woo S. 2014. A novel fungal metabolite with beneficial properties for agricultural applications. Molecules 19 (7): 9760-9772. DOI: 10.3390/molecules19079760.

Zambrano C, Kerekes EB, Kotogán A, Papp T, Vágvölgyi C, Krisch J, Takó M. 2019. Antimicrobial activity of grape, apple and pitahaya residue extracts after carbohydrase treatment against food-related bacteria. LWT Food Sci Technol 100: 4160-425. DOI: 10.1016/j.lwt.2018.10.044 .

Zipfel C. 2008. Pattern-recognition receptors in plant innate immunity. Curr Opin Immunol 20: 10-16. DOI: 10.1016/j.coi.2007.11.003 